\title{
METAMORFOSES DO TRABALHO NO ESTADO DO MATO GROSSO - BRASIL
}

METAMORPHOSES OF WORK IN THE STATE OF MATO GROSSO - BRAZIL

Luiz Felipe Ferrari Cerqueira de Farias ${ }^{\mathrm{A}}$

${ }^{\text {A }}$ Universidade de São Paulo (USP), São Paulo, SP, Brasil

Recebido em: 29/11/2021 | 04/01/2022～DOI: $10.12957 /$ tamoios.2022.63798

Correspondência para: Luiz Felipe Ferrari Cerqueira de Farias (luiz.fcdefarias@gmail.com)

Resumo: O objetivo deste artigo é investigar traços fundamentais do processo de formação da classe trabalhadora subordinada ao agronegócio no estado do Mato Grosso. Com base em uma revisão bibliográfica acerca da região e em dados dos Censos Demográficos e da Relação Anual de Informações Sociais (RAIS) do Ministério do Trabalho, analisaremos as transformações dos fluxos migratórios e do perfil dos trabalhadores que se dirigiram ao Mato Grosso desde 1960 até o presente momento. Em meio à expansão da cultura da soja e do complexo agroindustrial carnes/grãos durante as últimas décadas, destacaremos a permanência de um estado de inquietação social crônico dentre estes trabalhadores.

Palavras chave: Agronegócio; Trabalho rural; Trabalho agroindustrial

\begin{abstract}
The aim of this article is to investigate fundamental features of the making of the working class subordinated do agribusiness in the state of Mato Grosso (Brazil). Based on a review of the academic literature about the region and of data from the Demografic Censuses and from the Annual Report of Social Information (RAIS), we will analyse the changes in migrattory flows and in the profile of workers who went to Mato Grosso from the 1960s to present time. Amidst the expansion of soy cultivation and the meat/grain agroindustrial complex over the last few decades, we wil highlight the persistence of a state os chronic social unrest among those workers.
\end{abstract}

Keywords: Agribusiness; Rural labor; Agroindustrial labor 


\section{Introdução}

O objetivo deste artigo será apresentar traços fundamentais do processo de formação da classe trabalhadora subordinada ao "agronegócio" na região Centro-Oeste durante a segunda metade do século XX, mais especificamente no estado de Mato Grosso. Não nos deteremos nas múltiplas irregularidades do processo de transformação das terras públicas em propriedades privadas, nem nas inúmeras contradições dos projetos de colonização oficial e privada na região depois de 1964, que levaram a uma sistemática e violenta expropriação de terras indígenas e de posseiros no Cerrado como na Amazônia. Estes conflitos envolvendo a apropriação da terra são decisivos à compreensão da dinâmica socio-espacial da região, tendo já recebido um volume elevado de atenção por parte da investigação acadêmica especialmente nas áreas da geografia e da sociologia. Como complemento ao esforço coletivo para compreender a constituição da economia e da sociedade do "agronegócio", vamos nos ater neste artigo em específico ao processo contraditório e conflituoso de formação do mercado de trabalho assalariado que corre em paralelo a estas tensões envolvendo a terra na região.

Em um primeiro momento, vamos nos dedicar ao modo como a sociedade e o espaço no estado do Mato Grosso organizaram-se durante a ditadura entre 1964 e 1985 segundo os parâmetros da contra-reforma agrária, em um processo de acumulação primitiva do capital que lançou os fundamentos do que hoje chamamos de "agronegócio". Neste contexto, apresentaremos o processo desigual e combinado de proletarização de trabalhadores rurais que migraram para a região Centro-Oeste entre as décadas de 1960 e 1980, com especial destaque para a violenta espoliação do trabalho de peões na abertura de fazendas, de garimpeiros na extração do ouro e de prostitutas em bordéis da região. Buscaremos mostrar que estes trabalhadores foram submetidos a relações de produção mediadas por sistemática violência extra-econômica, com frequentes relatos de imobilização por dívida em condições que hoje chamamos "análogas à escravidão".

Em um segundo momento, vamos nos dedicar às metamorfoses do trabalho na região Centro-Oeste em meio à expansão da cultura da soja a partir da década de 1980 e da consolidação do complexo grão-carnes a partir da década de 2000. Neste contexto, deteremo-nos especialmente nas transformações do mercado de trabalho assalariado mato-grossense em um contexto de retração relativa da demanda de trabalho braçal nas lavouras e da proliferação de agroindústrias processadoras de soja e de carne, com destaque para alterações no volume e perfil da força de trabalho migrante na região. Veremos que esta classe trabalhadora subordinada ao agronegócio é crescentemente moldada pela urbanização dos principais municípios produtores de soja no estado, dotados de um espaço simultaneamente funcional às demandas do chamado "agronegócio" e marcado por contradições características de médias e grandes cidades.

Sustentaremos que parcela desta força de trabalho que se constituiu no estado do Mato Grosso nas últimas décadas corresponde ao que Ruy Braga denominou precariado, fração mais mal paga e explorada do proletariado urbano e dos trabalhadores agrícolas. Trata-se de uma fração de trabalhadores assalariados que se encontra em permanente trânsito entre a 
possibilidade de exclusão e o aprofundamento da exploração econômica, distinta da massa pauperizada composta por indigentes ou incapacitados para o trabalho bem como dos setores profissionais com maior remuneração, qualificação e estabilidade (Braga, 2012). Em sua interpretação acerca da política do precariado no Brasil, Braga parte da problematização de leituras sociológicas clássicas sobre o jovem operariado oriundo do Nordeste para indústrias do Sudeste entre os anos 1950 e 1960, supostamente caracterizado por um comportamento passivo e individualista avesso à formação de uma consciência de classe e modernas organizações políticas e sindicais. Segundo estas leituras, este jovem operariado seria marcado pela resiliência de modos de vida tradicionais rurais e por um sentimento de inépcia em sua auto-construção política, que o levariam a enxergar a manipulação por lideranças carismáticas interessadas no jogo eleitoral como única via possível de participação das massas na vida política nacional.

Em contraponto, Braga destaca o estado permanente de inquietação social deste jovem operariado migrante face a incapacidade do capitalismo periférico em conciliar acumulação de capital com extensão da cidadania salarial à população como um todo. Enfatizando a contradição entre a percepção de modesto progressos materiais do precariado e a angústia inerente à reprodução de sua subalternidade econômica e política, Braga convida-nos a uma investigação dos indícios ainda que amorfos e inorgânicos de inquietação que subjazem à aparente passividade desta fração da classe trabalhadora (Braga, 2012). Desde esta perspectiva político-metodológica, investigaremos o processo de formação da classe trabalhadora subordinada ao "agronegócio" em Mato Grosso por meio de uma arqueologia das especificidades de sua inquietação social.

\section{Peões, garimpeiros e prostitutas}

Ao longo da primeira metade do século $\mathrm{XX}$, a região Centro-Oeste como um todo apresentou taxas de crescimento demográfico inferiores à média nacional. A partir dos anos 1950 iniciou-se um intenso incremento populacional primeiramente no que hoje conhecemos como Mato Grosso do Sul e Goiás. A partir dos anos 1970 a taxa de crescimento demográfico acelerou-se também no que hoje chamamos Mato Grosso e Rondônia, devido especialmente ao fluxo migratório de trabalhadores do Centro-Sul com pouca ou nenhuma terra, atraídos pelos processos de colonização de áreas de fronteira agrícola. Como mostra a tabela 1, a taxa de crescimento demográfico anual do Mato Grosso foi de 6,6\% nos anos 1970 e 5,4\% nos anos 1980, multiplicando-se em 3,4 vezes a população do estado em um período de vinte anos. 
Tabela 1 - População total e taxa de crescimento médio segundo unidade da federação do Centro-Oeste, Rondônia e Tocantins entre 1970 e 1991

\begin{tabular}{c|c|c|c|c|c}
\hline & & & & \multicolumn{2}{|c}{$\begin{array}{c}\text { Taxa de crescimento } \\
\text { (\% a. a.) }\end{array}$} \\
$\begin{array}{c}\text { Unidade da } \\
\text { Federação }\end{array}$ & $\mathbf{1 9 7 0}$ & $\mathbf{1 9 8 0}$ & $\mathbf{1 9 9 1}$ & \multicolumn{2}{|c}{} \\
\cline { 5 - 6 } & & & & $\mathbf{7 0 / 8 0}$ & $\mathbf{8 0 / 9 1}$ \\
\hline DF & 537.492 & 1.176 .935 & 1.598 .415 & 8,15 & 2,82 \\
\hline GO & 2.414 .325 & 3.125 .354 & 4.012 .562 & 2,61 & 2,30 \\
\hline MT & $\mathbf{5 9 8 . 8 7 9}$ & $\mathbf{1 . 1 3 4 . 2 3 0}$ & $\mathbf{2 . 0 2 2 . 5 2 4}$ & $\mathbf{6 , 5 9}$ & $\mathbf{5 , 4 0}$ \\
\hline MS & 998.211 & 1.390 .019 & 1.778 .741 & 3,39 & 2,25 \\
\hline RO & 111.064 & 491.069 & 1.130 .874 & 16,03 & 7,88 \\
\hline TO & 516.447 & $\mathbf{7 4 3 . 7 5 0}$ & 920.116 & 3,71 & 1,95 \\
\hline Total & 5.176 .418 & 8.064 .357 & 11.463 .232 & 4,53 & 3,25 \\
\hline
\end{tabular}

(Cunha, 2002)

A reprodução ampliada da estrutura latifundiária em todo o Centro-Oeste, decorrência da contra-reforma agrária levada a cabo pela ditadura, criou obstáculos à absorção das massas de trabalhadores que migraram em direção à região. Em primeiro lugar, a sistemática expropriação de posseiros e as contradições dos projetos oficiais e privados de colonização impuseram limites à reprodução de pequenos produtores familiares nestas áreas de fronteira agrícola. Se entre 1970 e 1980 cerca de 31,4\% dos chefes de família imigrantes no Mato Grosso estabeleceram-se como "autônomos ou conta própria agropecuária" de acordo com os critérios do IBGE, entre 1980 e 1990 apenas 12,9\% o fizeram (Cunha, 2002). Paralelamente, a expansão da pecuária sobre a região e a subutilização de terras destinadas à especulação fundiária levaram a uma baixa geração de empregos permanentes nas zonas rurais do Centro-Oeste. Nesse contexto, se entre 1970 e 1980 16,3\% dos chefes de família imigrantes no Mato Grosso estabeleceram-se como empregados agropecuários (não volantes), entre 1980 e 1990 apenas 9,2\% foram capazes de fazê-lo. (Cunha, 2002).

Como consequência, os estados do Centro-Oeste rapidamente tornaram-se não apenas polos de atração, mas também de repulsão populacional. Como mostra a Tabela 2 abaixo, entre 1970 e 1980 a saída de migrantes foi similar ou mesmo superior a sua entrada no que hoje conhecemos como Mato Grosso do Sul e Goiás, sinal do esgotamento da capacidade destas áreas de absorver força de trabalho excedente do restante do país. Por sua vez, as áreas que hoje conhecemos como Mato Grosso e Rondônia receberam crescente volume de imigrantes durante a ditadura do capital sob tutela militar, mas ao longo dos anos 1980 viram também aumentar de maneira significativa a emigração de trabalhadores, com destaque para aqueles que abandonavam projetos de colonização e retornavam para os estados do Sul e 
Sudeste. Isso significa que estas áreas se converteram rápida e crescentemente não apenas em palcos de intensos conflitos pela posse e propriedade da terra, mas também em espaços de grande circulação de população plenamente expropriada e desenraizada, desempregada ou subempregada, em contínua busca por condições de sobrevivência no espaço rural ou urbano.

Tabela 2 - Volumes de imigração e emigração por unidade da federação do CentroOeste, Rondônia e Tocantins nas décadas de 70/80 e 81/91

\begin{tabular}{c|c|c|c|c|c|c}
\hline \multirow{2}{*}{ UF } & \multicolumn{3}{|c|}{$1970 / 1980$} & \multicolumn{3}{c}{$1981 / 1991$} \\
\cline { 2 - 7 } & Entrada & Saída & Saldo & Entrada & Saída & Saldo \\
\hline DF & 475.807 & 176.079 & 299.728 & 349.190 & 340.098 & 9.092 \\
\hline GO & 308.196 & 323.859 & -15.663 & 518.147 & 345.181 & 172.966 \\
\hline MT & $\mathbf{3 2 5 . 8 0 4}$ & $\mathbf{1 2 1 . 4 5 6}$ & $\mathbf{2 0 4 . 3 4 8}$ & $\mathbf{5 4 1 . 7 4 3}$ & $\mathbf{2 4 4 . 4 3 4}$ & $\mathbf{2 9 7 . 3 0 9}$ \\
\hline MS & 291.766 & 204.669 & 87.097 & 262.615 & 237.430 & 25.185 \\
\hline RO & 285.494 & 20.988 & 264.506 & 411.795 & 157.951 & 253.844 \\
\hline TO & 92.724 & 87.210 & 5.514 & 159.019 & 144.704 & 14.315 \\
\hline Total & 1.779 .791 & 934.261 & 845.530 & 2.242 .509 & 1.469 .798 & 772.711 \\
\hline
\end{tabular}

(Cunha, 2002)

Uma das principais atividades a absorver periódica e temporariamente estes trabalhadores no Mato Grosso entre as décadas de 1970 e 1980 foi a abertura de fazendas agropecuárias, em uma relação de produção conhecida como peonagem. Neste período, estas atividades envolviam primeiramente a abertura de "picadas" ou linhas divisórias das fazendas com foice, machado e facão e a limpeza do local destinado à sede e ao campo de pouso para aviões, imprescindíveis em locais isolados. Encaminhava-se então a feitura das cercas externas e internas, o que exigia o corte das "lascas" ou mourões, seu transporte e a abertura de buracos no chão para fixá-los, a colocação de arames com grampos e a limpeza do "aceiro" ou faixa de dois a três metros de ambos os lados da cerca para cortar o fogo das queimadas. Após o fim das chuvas, encaminhava-se o desmatamento: limpavam-se com foice os galhos finos, cipós e arbustos, realizava-se a derrubada de árvores com machado, moto-serra ou pesadas correntes presas a tratores e, enfim, fazia-se a queimada para eliminar o que não havia sido cortado anteriormente. Ao sinal das primeiras chuvas, realizava-se o plantio do capim sobre a cinza da queimada por meio de aviões ou manualmente por peões com sacos de sementes a tira-colo. Seguia-se por fim a limpeza periódica por dois a três anos da "juquira", ervas daninhas e brotação de árvores já derrubadas e queimadas que cresciam junto com o pasto. Uma vez formada a fazenda, a numerosa mão de obra temporária mobilizada para sua abertura já não era mais necessária, restando apenas pequeno número de empregados permanentes ou mensalistas (vaqueiros, maquinistas, motoristas e trabalhadores 
especializados ligados à administração): a fazenda Suiá Missú no nordeste do Mato Grosso, por exemplo, mobilizou cerca de 3.000 trabalhadores braçais para a abertura de 217 mil hectares destinados a atividades agropecuárias, mas criou apenas 250 postos de empregos fixos em sua operação (Martins, 1997).

Relação de produção característica ainda hoje da abertura de fazendas agropecuárias na Amazônia Legal, a peonagem possui uma série de especificidades. Para a realização de tarefas como as descritas acima o proprietário da fazenda em geral não arregimentava diretamente os trabalhadores, mas contratava um empreiteiro ou "gato" para fazê-lo. O "gato" deveria então calcular o número de trabalhadores necessários à realização do serviço, organizar equipamentos e mantimentos necessários à empreita, mobilizar supervisores ou "jagunços" que o apoiassem no controle dos peões e, enfim, recrutar a mão de obra direta ou indiretamente por meio de subempreiteiros ou "gatinhos". Estes intermediários não participavam diretamente do processo de trabalho, sua função prioritária era eximir os fazendeiros de quaisquer responsabilidades para com os peões: se a relação entre fazendeiro e "gato" era em geral mediada por contrato de prestação de serviço, a relação deste com os trabalhadores era mediada por acordos verbais distantes da aplicação de regulamentações trabalhistas. A intermediação da mão de obra tornou-se assim mecanismo eficaz de mistificação das tensões cotidianas no eito: quando confrontados com denúncias, fazendeiros usualmente declaravam não conhecer ou não ter controle sobre o modo como os empreiteiros atuavam. Nas palavras de Eujácio Ferreira de Almeida, proprietário da fazenda Moça Bonita em Eldorado dos Carajás: "Meu contrato é com o gato. Se ele matou o pai, a mãe ou algum peão, não me interessa. O que interessa é que me entregue a terra limpa" "Sem dó nem piedade", Veja, 14/04/1993 apud Le Breton, 2002, p. 77).

A característica fundamental da peonagem era o processo a partir do qual o trabalhador perdia a liberdade de vender sua força de trabalho, aprisionado em um sistema de servidão por dívidas. Quando aliciado pelo "gato", o peão frequentemente recebia um "abono" ou adiantamento em dinheiro destinado seja a manter sua família durante parte do período em que estivesse afastado, seja a financiar um último momento de diversões em bares e bordéis da cidade. Iniciava-se com isso uma dívida sobre a qual o trabalhador não tinha nenhum controle, acrescida pelos custos de transporte até o local da fazenda e pela compra de alimentos, remédios e mesmo instrumentos de trabalho na cantina organizada pelo "gato", usualmente a preços acima do mercado. A dívida crescente tornava-se então justificativa para a imobilização dos trabalhadores, sendo comuns relatos de peões que não conseguiam liquidar o débito que os aprisionava por mais que intensificassem suas atividades e reduzissem seus gastos. O consentimento dos peões a sua imobilização decorria ao menos parcialmente de uma coerção moral: o pagamento de uma dívida era aos seus olhos um princípio e a fuga do trabalhador em débito era um comportamento relativamente inadequado, apenas aceitável dentro de circunstâncias específicas. Ao fím da empreita o peão podia ou não receber um "saldo" (remuneração após desconto de despesas supostamente devidas), em geral rapidamente gasto em bares e bordéis da cidade após meses de confinamento na floresta. Sem recursos, o peão alimentava-se e hospedava-se às custas de uma pensão de onde apenas 
poderia sair se fosse recrutado para nova frente de trabalho por um "gato" que pagasse sua dívida, reiniciando o ciclo da peonagem (Esterci, 1987).

A sistemática violência física praticada por milícias privadas de jagunços ou por forças policiais sob controle dos grandes proprietários de terra foi mediação fundamental à reprodução da peonagem, expressão da contradição entre as demandas de acumulação do capital e as demandas da reprodução social dos trabalhadores migrantes em áreas de fronteira agrícola. Por um lado, as atividades de abertura de fazendas necessitavam de grande massa de peões concentrados em um só local, gerando uma situação de escassez relativa de mão de obra. Especialmente em um contexto de luta aberta pela terra, a violência extra-econômica buscava garantir a força o suprimento necessário de trabalhadores, em substituição a mecanismos coercitivos estritamente econômicos característicos de um mercado de trabalho livre assalariado. Por outro lado, a quantidade restrita de empregados permanentes que de fato operariam a fazenda fazia com que o peão se tornasse uma mão de obra descartável desde o ponto de vista do proprietário. Diferentemente da típica relação capitalista de produção em que a reprodução da força de trabalho é fundamental à acumulação de capital, na peonagem a empresa agropecuária podia prescindir totalmente da maior parte dos trabalhadores que inicialmente mobilizava para a formação do pasto, estabelecendo um estado de violência permanente e banalizada.

Assim como a peonagem, também o garimpo absorveu em toda Amazônia Legal e no Mato Grosso em particular amplas massas de trabalhadores migrantes sem terras. A partir de meados da década de 1970, o aumento dos preços internacionais do ouro e transformações técnicas que possibilitaram maior alcance e produtividade na extração aurífera e diamantífera deram impulso à retomada da atividade mineradora no estado, especialmente na região da baixada cuiabana em torno de Poconé, na região sudoeste mato-grossense em torno de Pontes e Lacerda, na região leste mato-grossense em torno de Nova Xavantina e na região norte mato-grossense em torno de Alta Floresta e Peixoto Azevedo. Este processo foi acompanhado de um significativo aumento dos fluxos migratórios intra e inter-estaduais em direção às áreas de garimpo: segundo Salomão, eram 86 mil os garimpeiros em atividade na Amazônia Legal ao final dos anos 1970 (Salomão, 1981); segundo Pasca, o número de garimpeiros na região amazônica em 1989 chegou a 900 mil, cerca de 320 mil deles no estado do Mato Grosso (Pasca, 1994). Compunham esta massa posseiros e colonos buscando suplementar o rendimento do lote familiar, peões em busca de alternativas à espoliação de seu trabalho e mesmo trabalhadores urbanos em situação de desemprego ou subemprego.

Os instrumentos e técnicas do garimpo no Brasil permaneceram até meados dos anos 1970 basicamente os mesmos do período colonial, com a utilização de ferramentas manuais para remoção da terra e exposição dos depósitos cascalhíferos, para a quebra e transporte do cascalho e para seu peneiramento e lavagem até a separação de ouro e/ou pedras preciosas. A partir de meados da década de 1970 iniciou-se a mecanização de todas as etapas da exploração de minérios na região amazônica: a extração da terra e exposição dos depósitos cascalhíferos passou a ser feita por meios hidráulicos ou com a lâmina do trator; a quebra e remoção dos sedimentos passou a ser realizada por meio de dragas compostas por 
moto-bombas e mangueiras de alta pressão e a apuração do cascalho passou a ocorrer em caixas metálicas com declive acentuado dotadas de sistemas de peneiras e forros onde o ouro e as pedras preciosas ficam retidos. Houve então uma gradual metamorfose das relações de produção em áreas de garimpo: o garimpeiro artesanal dotado de relativa autonomia de trabalho foi tendencialmente substituído por trabalhadores subordinados aos donos dos meios de produção, desde pequenos proprietários de máquinas até grandes empresas mineradoras nacionais e internacionais (Barrozo, 2007). Ainda assim, garimpeiros artesanais e semi-artesanais mantiveram-se entre os anos 1970 e 1980 como principais responsáveis pela extração de ouro e pedras preciosas na Amazônia Legal especialmente por meio da descoberta de novos depósitos ainda não explorados, atuando indiretamente como prospectores de empresas de mineração que posteriormente requeriam com sucesso áreas assim descobertas junto ao Estado.

Ao final da década de 1980 a atividade garimpeira na Amazônia Legal sofreu significativa queda devido à diminuição do preço internacional do ouro e à exaustão de depósitos acessíveis a técnicas artesanais e semi-artesanais de exploração, enquanto investimentos por parte das empresas mineradoras propiciaram um aumento progressivo na produção das minas industriais (Trindade e Filho, 2002). Conjunturalmente, o Plano Collor provocou drástica desorganização das atividades garimpeiras, uma vez que o sequestro das cadernetas de poupança e a imposição de limites aos saques nas contas bancárias levaram a súbita paralisação da compra de ouro e pedras preciosas (Lima, 2009). Neste contexto, áreas de garimpo tornaram-se polos de emigração de força de trabalho, em meio à decadência decorrente da devastação ambiental e da ausência de atividades econômicas alternativas: segundo reportagem de 02/02/1992 do jornal $A$ Gazeta de Cuiabá, a população garimpeira no Mato Grosso reduziu-se de 336 mil em 03/1990 para 186 mil em 12/1991 (Souza, 2007). Atraídos pela perspectiva de "bamburrar", alcançar riqueza rápida e abundante, garimpeiros terminaram sua trajetória em geral "blefados", esgotados economicamente e sem sombra das riquezas que no passado eventualmente passaram por suas mãos. Grande parte deles dirigiu-se para outras cidades da fronteira agrícola, recebidos por elites locais como elementos desagregadores da ética do trabalho e da moral familiar dos "pioneiros" (Souza, 2004).

Paralelamente à peonagem e ao garimpo, a prostituição também absorveu na Amazônia Legal grande quantidade de trabalhadoras em processo de proletarização e desenraizamento entre as décadas de 1970 e 1980. Especialmente em áreas de extração de ouro e diamante ou de abertura de fazendas agropecuárias, bordéis multiplicaram-se como espaços de sociabilidade fundamentais a garimpeiros e peões. Em sua pesquisa no início dos anos 1980 na região do Vale do Araguaia no nordeste mato-grossense, Esterci constatou que muitas das "meninas de ambiente" em boates e cabarés eram egressas de famílias de pequenos produtores rurais, assim como muitos peões. Inicialmente, haviam saído da casa dos pais em geral devido à ruptura de alguma regra do parentesco: ou haviam se "perdido" e quebrado o tabu da virgindade pré-matrimonial, ou haviam se "separado" e quebrado a perspectiva de perpetuação do vínculo conjugal. Assim como os peões de trecho, essas trabalhadoras 
permaneciam pouco tempo no mesmo lugar, mudando diversas vezes de cidade e de nome, em uma trajetória de corrosão da própria identidade (Esterci, 1994).

Em sua pesquisa a respeito da escravidão por dívidas no Pará e Mato Grosso, Figueira destacou o papel ambíguo das "meninas de ambiente" na peonagem, ora como mais um elo na corrente de aliciamento destes trabalhadores, ora como perspectiva de reconstrução de laços afetivos mais ou menos duradouros. Segundo o autor, por um lado, o cabaré cumpriu papel similar ao da pensão como espaço de endividamento de peões a serem posteriormente arregimentados por "gatos" para novas frentes de trabalho. Por outro lado, na medida em que as "meninas" tinham frequentemente a mesma origem social dos peões e sofriam como eles intensa discriminação social, formavam-se eventualmente relações de solidariedade mais ou menos estáveis entre eles (Figueira, 2004). Nestes casos, os “juntamentos" abriam para ambos novas perspectivas de inserção social: o peão teria maiores possibilidades de obter uma terra em áreas de posse ao (re)constituir uma família que o suportasse material e afetivamente, enquanto a "menina" poderia se libertar de uma atividade carregada de forte estigma, mesmo que em uma relação distinta do que era compreendido como casamento por posseiros e colonos (Figueira, Cerqueira, Oliveira, 2008).

Como obstáculo à reconstrução destes vínculos mínimos de solidariedade, Dimenstein constatou durante seu périplo no início dos anos 1990 pela Amazônia Legal (incluindo Cuiabá e áreas de garimpo no norte mato-grossense) a existência de um sistema de servidão por dívidas também em boates e cabarés. Atraídas por promessas de emprego e boa remuneração, as "meninas" eram enviadas por aliciadores para locais distantes e de difícil comunicação. Ao chegar eram informadas que tinham uma dívida decorrente do transporte até o local, que deveriam adquirir roupas, perfumes e mantimentos na cantina da boate a preços acima do mercado e que apenas poderiam sair quando saldassem o débito. Este frequentemente tornava-se impagável, de tal modo que o dinheiro obtido dos clientes nem passava pelas mãos da trabalhadora e ia direto para o caixa do estabelecimento, em um ciclo por vezes inescapável. Ocasionalmente o "passe" ou dívida das "meninas" era adquirido por outras boates ou indivíduos, em processos de compra e venda não da força de trabalho feminina mas sim das próprias trabalhadoras, que apenas se libertavam ao fugir, cair irremediavelmente doentes ou não mais atrair fregueses (Dimenstein, 1992).

Em dimensão ainda mais ampla que a apontada acerca da peonagem, o estado de violência permanente e banalizada a que estavam submetidas estas trabalhadoras era mediação fundamental a sua imobilização. Em primeiro lugar, segundo Dimenstein, elas frequentemente relatavam abusos físicos e sexuais no ambiente doméstico desde tenra idade, em geral cometidos por pessoas íntimas, impulsionando-as à fuga de casa e à aceitação de propostas de aliciadores. Uma vez aprisionadas pela dívida, eram coagidas sob permanente ameaça de maus tratos e agressões a uma atividade sexual intensa, com conivência passiva ou ativa de forças policiais locais. Por fim, eram frequentemente submetidas a agressões por parte por seus clientes, peões ou garimpeiros que eventualmente reagiam à posição de impotência a que haviam sido reduzidos por meio da reafirmação de seu poder sobre outros mais fracos que eles. Articulavam-se e sucediam-se assim conflitos decorrentes da condição 
de classe e da condição de gênero destas trabalhadoras, em um caleidoscópio de violências a reproduzir sua subalternidade.

Estes personagens ilustram o conturbado processo de proletarização em Mato Grosso entre os anos 1960 e 1980, quando massas de migrantes expropriados e desenraizados não foram absorvidas por um mercado de trabalho livre assalariado estruturado e mediado por relações contratuais. Em um contexto de acumulação primitiva do capital, foram em geral submetidas a relações de produção mediadas pela sistemática violência extra-econômica. A forma mais usual de resistência de trabalhadores e trabalhadoras a este contexto de espoliação foi a fuga e a contínua circulação em busca de condições mínimas de sobrevivência, retardando a construção de laços de solidariedade que poderiam dar substância a organizações coletivas de representação de setores subalternos da sociedade mato-grossense. Por um lado, em seu movimento de uma cidade, de um estado, de uma região à outra, peões, garimpeiros e prostitutas viram dissolverem-se seu nome de batismo, seus documentos de identidade e outras referências sociais básicas de seus grupos de origem. Por outro, invisíveis a uma estrutura sindical incapaz no mais das vezes de superar seu caráter predominantemente formal, estes personagens viram sua inquietação assumir frequentemente a forma de comportamentos auto-destrutivos, como o consumo abusivo de álcool e atos de violência banalizada. Privados tanto dos parâmetros da sociabilidade camponesa de seus locais de origem, quanto de ferramentas para a construção de novas identidades e organizações coletivas, foram reduzidos na narrativa dominante dos prósperos "pioneiros" em projetos privados de colonização a perturbações contra a ordem estabelecida face as quais seria necessário mobilizar ferramentas de exclusão e vigilância no espaço rural e urbano.

\section{Trabalhadores assalariados em fazendas, agroindústrias e na construção civil}

O processo de expansão da soja a partir dos anos 1980 foi acompanhado por uma redução significativa do crescimento demográfico nos estados da região Centro-Oeste. Destaca-se neste contexto o estado de Mato Grosso, que viu a taxa anual de aumento de sua população diminuir de 5,4\% entre 1980 e 1991 para 1,9\% entre 2000 e 2010. Como destaca Cunha em estudo acerca do processo de ocupação recente no Mato Grosso, entre as décadas de 1990 e 2000 ocorreu um arrefecimento da dinâmica demográfica típica da fronteira agrícola que caracterizara o estado durante as décadas de 1960 a 1980 (Cunha, 2011). Dentre outros fatores, isso decorre do fato de que a expansão da soja sobre o Mato Grosso consolidou obstáculos ao fluxo de trabalhadores, com destaque para a baixa geração de empregos no interior de grandes propriedades rurais e para os constrangimentos à reprodução da agricultura familiar. Condizentes com este quadro, o saldo entre entradas e saídas migratórias em Mato Grosso reduziu-se de 295 mil pessoas entre 1980-1991 para 127 mil pessoas entre 2000-2010, indicando um enfraquecimento da perspectiva da população especialmente oriunda do Sul de ali encontrar terra e/ou trabalho (Cunha 2015). 
Tabela 3 - População total e taxa de crescimento médio segundo Lnidade da Federação do Centro-Oeste entre 1980 e 2010

\begin{tabular}{|c|c|c|c|c|c|c|}
\hline \multirow[t]{2}{*}{ UFs } & \multirow[t]{2}{*}{1991} & \multirow[t]{2}{*}{2000} & \multirow[t]{2}{*}{2010} & \multicolumn{3}{|c|}{$\begin{array}{c}\text { Taxa de crescimento } \\
\text { ( } \% \text { ao ano) }\end{array}$} \\
\hline & & & & $1980 / 1991$ & $1991 / 2000$ & $\begin{array}{c}2000 \\
2010\end{array}$ \\
\hline DF & 1.598 .415 & 2.043 .169 & 2.570 .160 & 2,8 & 2,8 & 2.3 \\
\hline GO & 4.012 .562 & 4.996 .439 & 6.003 .788 & 2,3 & 2,5 & 1.8 \\
\hline MT & 2.022 .524 & 2.502 .260 & 3.035 .122 & 5,4 & 2,3 & 1,9 \\
\hline MS & 1.778 .741 & 2.074 .877 & 2.449 .024 & 2,2 & 1,8 & 1.7 \\
\hline Total & 9.412 .242 & 11.616 .745 & 14.058 .094 & 2,3 & 2,4 & 1.9 \\
\hline
\end{tabular}

(Camargo, 2016)

Estas transformações dentre os fluxos migratórios para e desde o estado do Mato Grosso foram acompanhadas por amplas metamorfoses do mundo do trabalho na região. É necessário inicialmente destacar alterações significativas na distribuição geográfica dos trabalhadores submetidos a condições análogas à escravidão durante as últimas décadas. A tabela 4 mostra que Pará e Mato Grosso lideram a lista de estados com maior número de trabalhadores libertados entre 1995 e 2014 pelo Grupo Especial de Fiscalização Móvel (GEFM), coordenado pela Secretaria de Inspeção do Trabalho (SIT) do Ministério do Trabalho e Emprego (MTE). Entretanto, os dados mostram que a participação do estado do Mato Grosso no número de trabalhadores libertados em todo o país decresceu continuamente de $46 \%$ no período entre 1995 e 1998 para 6,5\% entre 2007 e 2010, alcançando 2,3\% entre 2010 e 2014. Em primeiro lugar, isto é reflexo da diversificação dos trabalhos de fiscalização, que revelaram a existência de trabalho em condições análogas à escravidão em regiões e setores cada vez mais amplos, com destaque para as cadeias produtivas de açúcar e álcool, confecção de roupas e construção civil especialmente no estado de São Paulo. Neste contexto, em 2013 pela primeira vez o número de escravos encontrados em atividades urbanas ultrapassou o de trabalhadores em atividades agrícolas no país (Plassat, 2015). Em segundo lugar, a diminuição da participação de Mato Grosso dentre os estados com maior número de trabalhadores libertados decorre também do movimento da fronteira agrícola e do arco de desmatamento em direção ao norte. Enquanto as principais regiões produtoras de soja altamente capitalizadas no estado do Mato Grosso empregam relativamente menos trabalhadores agrícolas com qualificação crescente, no estado do Pará segue recorrente o típico escravo contemporâneo brasileiro: migrantes do Maranhão, norte de Tocantins ou oeste do Piauí, de sexo masculino, analfabetos funcionais, levados para as fronteiras da Amazônia em municípios de criação 
recente e utilizados principalmente em atividades vinculadas ao desmatamento (Therry, Melo, Hato e Girardi, 2009). Em terceiro lugar, a redução relativa na incidência de flagrantes de trabalho escravo no estado do Mato Grosso é consequência da multiplicação de exigências socioambientais por mercados externos, levando produtores rurais a buscar selos de certificação internacional de boas práticas agrícolas. Dentre as principais iniciativas nesse sentido na sojicultura destacam-se a Round Table on Responsible Soybean Association (plataforma global que visa o estabelecimento de critérios para a produção dita "sustentável" de soja) e o Soja Plus (programa de gestão da propriedade que auxilia os produtores rurais com qualificação para o cumprimento das legislações ambiental e trabalhista brasileiras) (Wesz Júnior, 2014).

Tabela 4: Número de trabalhadores escravizados libertados por Unidade da Federação entre 1995 e 2014

\begin{tabular}{|c|c|c|c|c|c|c|c|c|c|c|c|c|}
\hline UFs. & 1995-1998 & $\%$ & $1999-2002$ & $\%$ & 2003-2006 & $\%$ & $2007-2010$ & $\%$ & 2011-2014 & $\%$ & Total & $\%$ \\
\hline $\mathrm{AC}$ & - & - & - & - & 8 & 0,1 & 24 & 0,1 & 102 & 1,1 & 134 & 0,3 \\
\hline $\mathrm{AL}$ & - & - & - & - & - & - & 656 & 3,8 & 93 & 1,0 & 749 & 1,6 \\
\hline AM & - & - & - & - & 28 & 0,2 & 104 & 0,6 & 278 & 2,9 & 410 & 0,9 \\
\hline BA & - & - & - & - & 1.942 & 12,9 & 667 & 3,8 & 371 & 3,9 & 2.980 & 6,2 \\
\hline CE & - & - & - & - & 88 & 0,6 & 231 & 1,3 & 146 & 1,5 & 465 & 1,0 \\
\hline ES & - & - & - & - & 244 & 1,6 & 317 & 1,8 & 152 & 1,6 & 713 & 1,5 \\
\hline MA & 8 & 0,8 & 668 & 14,5 & 1.175 & 7,8 & 745 & 4,3 & 342 & 3,6 & 2.938 & 6,2 \\
\hline MT & 489 & 46,0 & 1.268 & 27,5 & 2.865 & 19,0 & 1.122 & 6,5 & 225 & 2,3 & 5.969 & 12,5 \\
\hline MS & 50 & 4,7 & 152 & 3,3 & 74 & 0,5 & 1.912 & 11,0 & 545 & 5,7 & 2.733 & 5,7 \\
\hline MG & 46 & 4,3 & 24 & 0,5 & 119 & 0,8 & 1.584 & 9,1 & 2.278 & 23,7 & 4.051 & 8,5 \\
\hline PA & 386 & 36,3 & 2.256 & 48,9 & 4.985 & 33,1 & 3.622 & 20,9 & 1.062 & 11,1 & 12.311 & 25,8 \\
\hline PE & - & - & - & - & - & - & 728 & 4,2 & 41 & 0,4 & 769 & 1,6 \\
\hline RJ & - & - & - & - & 215 & 1,4 & 674 & 3,9 & 391 & 4,1 & 1.280 & 2,7 \\
\hline RN & - & - & - & - & 29 & 0,2 & 7 & 0,0 & - & - & 36 & 0,1 \\
\hline RS & - & - & - & - & 35 & 0,2 & 93 & 0,5 & 142 & 1,5 & 270 & 0,6 \\
\hline RO & - & - & 42 & 0.9 & 415 & 2,8 & 128 & 0,7 & 150 & 1,6 & 735 & 1,5 \\
\hline RR & - & - & - & - & - & - & 26 & 0,2 & 25 & 0,3 & 51 & 0,1 \\
\hline SC & - & - & - & - & 54 & 0,4 & 535 & 3,1 & 229 & 2,4 & 818 & 1,7 \\
\hline SP & - & - & 76 & 1,6 & 111 & 0,7 & 322 & 1,9 & 1.021 & 10,6 & 1.530 & 3,2 \\
\hline TO & - & - & 46 & 1,0 & 1.551 & 10,3 & 614 & 3,5 & 564 & 5,9 & 2.775 & 5,8 \\
\hline Total & 1.062 & 100 & 4.611 & 100 & 15.080 & 100 & 17.328 & 100 & 9.609 & 100 & 47.690 & 100 \\
\hline
\end{tabular}

(Secretaria de Inspeção do Trabalho - SIT)

Neste contexto, as características mais salientes dos principais polos sojicultores do Mato Grosso ao longo das últimas décadas tem sido a adoção de novos sistemas técnicos e a mobilização de trabalhadores rurais dotados de um novo perfil. Segundo Aracri, as décadas de 1980 e 1990 foram marcadas pela introdução e disseminação das inovações da Revolução Verde na produção de soja no estado, crescentemente pautada pelas técnicas de mecanização, de correção química dos solos e de seleção e melhoramento genético de sementes adaptadas às condições locais. Segundo o autor, a partir da década de 2000 vem se destacando a introdução e difusão na sojicultura mato-grossense da assim chamada agricultura de precisão: sistema que integra tecnologias de comunicação e informação a equipamentos agrícolas em 
um ciclo de análise do solo para mapear variações de produtividade no interior do estabelecimento, aplicação de corretivos e fertilizantes a taxas variáveis de acordo com as características de cada área, plantio a taxas variáveis de acordo com os diferentes potenciais produtivos na propriedade e colheita por meio de máquinas com sensores de produtividade de maneira a atualizar periodicamente o mapeamento do solo da fazenda (Aracri, 2010). Conforme pesquisa sobre mecanização agrícola em Mato Grosso publicada pelo IMEA em junho de 2015 , cerca de $42 \%$ de um universo de 318 proprietários com um total de 710 mil hectares ( $8 \%$ da área com soja no estado naquele ano) declararam utilizar agricultura de precisão. Ainda segundo esta pesquisa, a maior parte dos entrevistados afirmou ter começado a adotar este sistema técnico a partir da renovação do parque de máquinas nos cinco anos anteriores (IMEA, 2015).

Este processo de modernização técnica da produção agrícola não eliminou a necessidade de força de trabalho não qualificada, empregada temporariamente em serviços gerais como "catação de raízes" (limpeza do terreno para possibilitar o trabalho das máquinas), carregamentos de caminhões, corte e movimentação de lenha, levantamento de cercas, cozinha e limpeza, manipulação de máquinas agrícolas pouco complexas, etc. Conforme pesquisa de campo realizada entre maio e julho de 2008 no município de Sorriso (MT), Rumstain chama a atenção para o volume elevado de homens que chegavam em ônibus formais ou clandestinos de estados do Nordeste (especialmente do Maranhão), desde aqueles que possuíam calendário fixo de trabalho em fazendas de soja e milho da região até aqueles que vinham "tentar a sorte" sem local para se fixar ou emprego certo. Similarmente à peonagem descrita anteriormente, estes trabalhadores tinham como característica um elevado grau de mobilidade, oscilando entre empregos na agricultura e na construção civil, deslocando-se a novas regiões com base em informações sobre oportunidades de trabalho e retornando periodicamente a seus estados natais. Contrariamente às relações características da peonagem anteriormente destacadas, contudo, estes trabalhadores estiveram inseridos em um contexto de crescente formalização do vínculo empregatício a partir dos anos 2000, permitindo-lhes acesso ao seguro desemprego e ao "acordo" ao fim da safra (décimo terceiro, férias, FGTS e participação nos lucros proporcionais ao tempo de trabalho) (Rumstain, 2012).

Entretanto, na medida em que se consolidaram regiões produtoras de soja e avançou o progresso técnico no interior das fazendas do estado do Mato Grosso, reduziu-se relativamente sua capacidade de absorver mão de obra não qualificada e ampliou-se a demanda por trabalhadores qualificados capazes de interpretar dados e tomar decisões ao manipular máquinas crescentemente complexas e plurifuncionais. Passou-se deste modo de um ritmo de trabalho submetido ao controle ostensivo para outro submetido ao controle remoto, em que trabalhadores operam máquinas sofisticadas no interior de cabines confortáveis dotadas de música e ar refrigerado enquanto são cercados de dispositivos transmissores de seu comportamento que exigem rígida disciplina de horários e sanções em nome do incremento da produtividade (Bernardes, 2005). Em pesquisa acerca do mercado de trabalho assalariado na agricultura brasileira entre 1992 e 2004, Balsadi aponta que já neste 
período era perceptível um aumento do nível de rendimento, do grau de formalidade e do nível educacional de empregados permanentes na lavoura de soja (Balsadi, 2008).

Como resultado destas transformações, a Pesquisa Nacional por Amostra de Domicílio (PNAD) aponta que a participação dos trabalhadores agrícolas dentre a força de trabalho assalariada no Mato Grosso reduziu-se de $19 \%$ para $14,3 \%$ entre 2003 e 2015 . Isso equivale a dizer que a expansão acelerada da cultura da soja foi acompanhada de uma diminuição relativa da capacidade das fazendas de absorver fluxos migratórios de mão de obra braçal não qualificada. Dados da PNAD também mostram que a parcela de trabalhadores agrícolas com carteira assinada no estado do Mato Grosso saltou de 39,9\% em 2003 para 71,2\% em 2015, enquanto no mesmo período o nível de formalização dos trabalhadores da indústria passou de $64,2 \%$ para $80,8 \%$. Paralelamente, houve um aumento significativo do nível educacional da força de trabalho empregada formalmente na cultura de grãos no estado do Mato Grosso, como ilustra a tabela 5 com dados partir da Relação Anual de Informações Sociais (RAIS) acerca de trabalhadores no estado do Mato Grosso envolvidos no cultivo de soja (CNAE 0115-6/00) e no cultivo de milho (CNAE 0111-3/02). Trabalhadores com até ensino fundamental completo diminuíram sua participação no interior de fazendas de soja mato-grossenses de $69,2 \%$ em 2006 para 44,8\% em 2018, enquanto os com ensino médio incompleto e completo saltaram de $26,9 \%$ para $46,7 \%$. De acordo com a tabela 6 , dados da RAIS também mostram que aumentou a remuneração média dos empregados com carteira assinada na sojicultura em Mato Grosso, ainda que em uma escala inferior ao aumento da qualificação da mão de obra. Trabalhadores com até 2 salários mínimos reduziram sua participação em fazendas de soja mato-grossenses de cerca de 43,6\% em 2006 para cerca de 33,3\% em 2018, enquanto os com 2 a 5 salários mínimos aumentaram de $51,2 \%$ para $59,4 \%$. 
Tabela 5: Número de pessoas empregadas com carteira assinada no cultivo de soja e milho por grau de escolaridade no estado do Mato Grosso entre 2006 e 2018

\begin{tabular}{|c|c|c|c|c|c|c|c|c|}
\hline $\begin{array}{c}\text { Grau de } \\
\text { escolaridade }\end{array}$ & 2006 & $\%$ & 2010 & $\%$ & 2014 & $\%$ & 2018 & $\%$ \\
\hline Analfabeto & 355 & 1,69 & 497 & 1,5 & 579 & 1,26 & 575 & 1,04 \\
\hline $\begin{array}{l}\text { Fundamental I } \\
\text { incompleto }\end{array}$ & 2.232 & 10,65 & 3.864 & 11,7 & 4.965 & 10,83 & 5.121 & 9,3 \\
\hline $\begin{array}{l}\text { Fundamental I } \\
\text { completo }\end{array}$ & 3.067 & 14,64 & 3.287 & 9,95 & 3.313 & 7,22 & 3.157 & 5,73 \\
\hline $\begin{array}{l}\text { Fundamental } \\
\text { II incompleto }\end{array}$ & 5.494 & 26,22 & 7.409 & 22,43 & 8.149 & 17,77 & 9.105 & 16,54 \\
\hline $\begin{array}{l}\text { Fundamental } \\
\text { II completo }\end{array}$ & 3.353 & 16 & 4.833 & 14,63 & 6.536 & 14,25 & 6.744 & 12,25 \\
\hline $\begin{array}{c}\text { Médio } \\
\text { incompleto }\end{array}$ & 2.219 & 10,59 & 3.688 & 11,17 & 5.326 & 11,61 & 7.060 & 12,82 \\
\hline $\begin{array}{l}\text { Médio } \\
\text { completo }\end{array}$ & 3.427 & 16,36 & 7.695 & 23,30 & 13.539 & 29,52 & 18.678 & 33,92 \\
\hline $\begin{array}{c}\text { Superior } \\
\text { incompleto }\end{array}$ & 261 & 1,25 & 553 & 1,67 & 987 & 2,15 & 1.106 & 2,01 \\
\hline $\begin{array}{l}\text { Superior } \\
\text { completo }\end{array}$ & 527 & 2,52 & 1.190 & 3,60 & 2.383 & 5,20 & 3.478 & 6,32 \\
\hline Mestrado & 8 & 0,04 & 8 & 0,02 & 70 & 0,15 & 30 & 0,05 \\
\hline Doutorado & 10 & 0,05 & 3 & 0,01 & 12 & 0,03 & 11 & 0,02 \\
\hline Total & 20.953 & 100 & 33.027 & 100 & 45.859 & 100 & 55.065 & 100 \\
\hline
\end{tabular}

(MTE - Relação Anual de Informações Sociais) 
Tabela 6: Número de pessoas empregadas com carteira assinada no cultivo de soja e milho por faixa de remuneração média em Mato Grosso entre 2006 e 2018

\begin{tabular}{|c|c|c|c|c|c|c|c|c|}
\hline $\begin{array}{c}\text { Faixa de } \\
\text { remuneração } \\
\text { média (SM) }\end{array}$ & 2006 & $\%$ & 2010 & $\%$ & 2014 & $\%$ & 2018 & $\%$ \\
\hline Até 0,5 & 19 & 0,09 & 45 & 0,14 & 36 & 0,08 & 170 & 0,31 \\
\hline 0,5 a 1 & 975 & 4,65 & 1.218 & 3,69 & 998 & 2,18 & 1.080 & 1,96 \\
\hline 1 a 1,5 & 3.242 & 15,47 & 4.612 & 13,96 & 5.351 & 11,67 & 5.942 & 10,79 \\
\hline 1,5 a 2 & 4.907 & 23,42 & 7.086 & 21,46 & 7.914 & 17,26 & 11.158 & 20,26 \\
\hline 2 a 3 & 7.090 & 33,84 & 11.703 & 35,43 & 16.299 & 35,54 & 19.898 & 36,14 \\
\hline 3 a 4 & 2.766 & 13,2 & 4.895 & 14,82 & 8.243 & 17,97 & 9.523 & 17,29 \\
\hline 4 a 5 & 866 & 4,13 & 1.549 & 4,69 & 3.413 & 7,44 & 3.299 & 5,99 \\
\hline 5 a 7 & 539 & 2,57 & 932 & 2,82 & 1.932 & 4,21 & 2.003 & 3,64 \\
\hline 7 a 10 & 255 & 1,22 & 400 & 1,21 & 635 & 1,38 & 682 & 1,24 \\
\hline Mais de 10 & 131 & 0,63 & 216 & 0,65 & 421 & 0,92 & 510 & 0,93 \\
\hline \{ñ class\} & 163 & 0,78 & 371 & 1,12 & 617 & 1,35 & 800 & 1,45 \\
\hline Total & 20.953 & 100 & 33.027 & 100 & 45.859 & 100 & 55.065 & 100 \\
\hline
\end{tabular}

\section{(MTE - Relação Anual de Informações Sociais)}

Paralelamente a estas transformações, vem se consolidando nas últimas décadas em Mato Grosso a cadeia carne/grãos, com amplas repercussões sobre o mercado de trabalho no estado como um todo e em seus polos produtores de soja e milho em particular. Especialmente após a segunda metade da década de 2000 vem ocorrendo um nítido processo de diversificação e verticalização da estrutura produtiva do chamado "agronegócio" em Mato Grosso: a soja serve de matéria prima às indústrias esmagadoras de grãos, enquanto o óleo produzido por estas serve de matéria prima para indústrias de biodiesel e o farelo (juntamente com o milho) serve de matéria prima para as fábricas de rações, que por sua vez alimentam os rebanhos de bovinos, suínos e aves que servem de insumo às agroindústrias processadoras de carnes. Segundo a Associação Brasileira das Indústrias de Óleos Vegetais, a capacidade de processamento das esmagadoras de grãos instaladas no estado do Mato Grosso saltou de 10.520 toneladas/dia ou 8,2\% da capacidade instalada da indústria no Brasil em 2000 para 41.897 toneladas/dia ou $21,7 \%$ da capacidade instalada total no país em 2018. Segundo a Agência Nacional do Petróleo, Gás Natural e Biocombustíveis, a produção de biodiesel puro 
(B100) apenas teve início no estado do Mato Grosso no ano de 2007, mas alcançou a marca de $1.133 .560 \mathrm{~m}^{3}$ ou $21,2 \%$ da produção em todo país em 2018. Segundo o Instituto Brasileiro de Geografia e Estatística, o número de abates de bovinos realizados por frigoríficos no estado do Mato Grosso aumentou de 1.923 .422 ou 11,2\% de abates no país em 2000 para 5.219.350 ou 16,3\% de abates em 2018. Com uma dimensão menor, porém crescente, o número de abates de suínos em frigoríficos no estado do Mato Grosso passou de 245.746 ou $1,5 \%$ dos porcos abatidos no país em 2000 para 2.497 .715 ou 5,6\% dos porcos abatidos em 2018. Com uma dinâmica similar, o número de aves abatidas em agroindústrias processadoras de carnes no estado do Mato Grosso saltou de 46.997 .476 ou 1,8\% dos abates realizados no país em 2000 para 215.717.180 ou 3,8\% das aves abatidas em 2018. Havia em 2012 em operação no estado do Mato Grosso 14 indústrias esmagadoras de grãos, 20 usinas autorizadas a produzir biodiesel, 39 processadoras de carne bovina, 9 processadoras de carne suína e 7 processadoras de carne de aves (IMEA, 2012).

A crescente participação das indústrias esmagadoras de soja e das usinas de produção de biodiesel no estado do Mato Grosso foi concomitante a um aumento na escala das plantas industriais e no grau de automação e informatização de suas linhas. Segundo Wesz Júnior, a partir do início dos anos 2000 ocorreu uma expansão de unidades esmagadoras com capacidade de processamento maior que três mil $t / d i a$, enquanto praticamente desapareceram do setor aquelas com capacidade até 599 t/dia correspondentes a pequenas e médias agroindústrias locais especialmente na região Sul (Wesz Júnior, 2011). No mesmo sentido, também a expansão de agroindústrias de processamento de carne no Mato Grosso foi acompanhada de um aumento na escala das plantas industriais com amplos impactos nos mercados de trabalho locais e regionais. Dentre as maiores indústrias frigoríficas inauguradas ao longo da década de 2000 no estado destacam-se especialmente a unidade da Brasil Foods no município de Nova Mutum com cerca de 2.200 funcionários e a unidade da mesma empresa no município de Lucas do Rio Verde com cerca de 4.500 funcionários, este o maior frigorífico da América Latina em extensão e o terceiro maior do Brasil em número de empregados.

Esta expansão agroindustrial foi acompanhadas de mudanças no perfil dos operários, como ilustram as tabelas 7 e 8 compostas de dados obtidos a partir da RAIS acerca de trabalhadores no estado do Mato Grosso envolvidos na fabricação de tortas, farinhas e farelos de sementes oleaginosas e de óleos vegetais em bruto, exceto óleo de milho (CNAE 1041-4/00), na fabricação de biocombustíveis, exceto álcool (CNAE 1932-2/00), em atividades de armazenamento e depósito, inclusive em câmaras frigoríficas e silos (CNAE 5211-7/99), no abate de bovinos (CNAE 1011-2/01), no abate de aves (CNAE 1012-1/01), no abate de suínos (CNAE 1012-1/03), na fabricação de produtos de carne (CNAE 1013-9/01) e na preparação de subprodutos do abate (CNAE 1013-9/02). Podemos acompanhar nestas tabelas uma elevação significativa da qualificação da força de trabalho no interior das agroindústrias, como já víramos em fazendas de soja e milho. A participação nestes setores agroindústrias de trabalhadores com até o ensino fundamental completo caiu de $59 \%$ em 2006 para $25 \%$ em 2018 , enquanto a participação dos com ensino médio incompleto e completo 
aumentou de $35 \%$ para $62 \%$ no período. Contudo, o nível de remuneração não acompanhou o aumento na qualificação da força de trabalho: a participação de trabalhadores que recebiam até 2 salários mínimos oscilou de 58\% em 2006 para 57\% em 2018, enquanto a participação dos com remuneração de 2 a 5 salários mínimos oscilou de $35 \%$ para $34 \%$ no período.

Ademais, este aumento da qualificação da força de trabalho tampouco foi acompanhada de uma melhoria significativa de condições de trabalho na agroindústria, especialmente no interior das plantas processadoras de carnes bovinas, suínas e de aves. A maioria dos equipamentos em frigoríficos se utiliza atualmente de tecnologia eletromecânica, hidráulica ou pneumática no processo desde o abate até a embalagem, mas a ferramenta mais utilizada pelos trabalhadores ainda continua sendo a faca em uma mão e o gancho na outra para se evitar o contato físico direto com a carne dos animais. Atividades em frigoríficos cobram destreza e rapidez manual para realizar os cortes nos animais de acordo com o ritmo estabelecido pelas linhas de produção e a grande quantidade de movimentos repetitivos resulta em frequentes Lesões Por Esforço Repetitivo ou Doenças Osteomusculares Relacionadas ao Trabalho (LER/DORT). Segundo o Tribunal Regional do Trabalho do Mato Grosso o setor de abate de animais liderou o ranking de acidentes de trabalho no estado entre os anos de 2012 e 2018 com 10.363 casos ou 17,5\% das ocorrências neste período, seguido por atividades no cultivo de soja com 4.327 casos ou 7,16\% das ocorrências no mesmo período (G1, "Setor de abate de animais lidera ranking de acidentes de trabalho em MT, diz TRT”, 02/05/2018). 
Tabela 7: Número de pessoas empregadas com carteira assinada no armazenamento e processamento de grãos e carnes por grau de escolaridade em Mato Grosso entre 2006 e 2018

\begin{tabular}{|c|c|c|c|c|c|c|c|c|}
\hline $\begin{array}{c}\text { Grau de } \\
\text { escolaridade }\end{array}$ & 2006 & $\%$ & 2010 & $\%$ & 2013 & $\%$ & 2018 & $\%$ \\
\hline Analfabeto & 244 & 1,0 & 216 & 0,7 & 276 & 0,7 & 158 & 0,4 \\
\hline $\begin{array}{l}\text { Fundamental } \\
\text { I incompleto }\end{array}$ & 1.336 & 5,7 & 2.062 & 6,7 & 2.430 & 6,2 & 1.349 & 3,6 \\
\hline $\begin{array}{l}\text { Fundamental } \\
\text { I completo }\end{array}$ & 2.231 & 9,5 & 2.404 & 7,8 & 2.960 & 7,5 & 1.080 & 2,9 \\
\hline $\begin{array}{l}\text { Fundamental } \\
\text { II incompleto }\end{array}$ & 6322 & 26,9 & 4.901 & 16 & 5.815 & 14,8 & 3.368 & 9,1 \\
\hline $\begin{array}{l}\text { Fundamental } \\
\text { II completo }\end{array}$ & 3.980 & 16,0 & 3.497 & 11,4 & 4.161 & 10,6 & 3.341 & 9 \\
\hline $\begin{array}{c}\text { Médio } \\
\text { incompleto }\end{array}$ & 3.371 & 14,4 & 4.513 & 14,7 & 7.182 & 18,2 & 4.747 & 12,8 \\
\hline $\begin{array}{l}\text { Médio } \\
\text { completo }\end{array}$ & 5.003 & 21,3 & 10.034 & 32,7 & 13.171 & 33,5 & 18.424 & 49,8 \\
\hline $\begin{array}{c}\text { Superior } \\
\text { incompleto }\end{array}$ & 413 & 1,8 & 1.635 & 5,3 & 1.577 & 4 & 983 & 2,7 \\
\hline $\begin{array}{l}\text { Superior } \\
\text { completo }\end{array}$ & 581 & 2,5 & 1.401 & 4,6 & 1.759 & 4,5 & 3.501 & 9,5 \\
\hline Mestrado & 3 & 0 & 10 & 0 & 22 & 0,1 & 22 & 0,1 \\
\hline Doutorado & 1 & 0 & 3 & 0 & 0 & 0 & 1 & 0 \\
\hline Total & 23.485 & 100 & 30.676 & 100 & 39.356 & 100 & 36.974 & 100 \\
\hline
\end{tabular}


Tabela 8: Número de pessoas empregadas com carteira assinada no armazenamento e no processamento de grãos e carnes por faixa de remuneração no estado do Mato Grosso entre 2006 e 2018

\begin{tabular}{c|c|c|c|c|c|c|c|c}
\hline $\begin{array}{c}\text { Faixa de } \\
\text { remuneração } \\
\text { média (SM) }\end{array}$ & $\mathbf{2 0 0 6}$ & $\%$ & $\mathbf{2 0 1 0}$ & $\%$ & $\mathbf{2 0 1 3}$ & $\%$ & $\mathbf{2 0 1 8}$ & $\%$ \\
\hline Até 0,5 & 17 & 0,1 & 61 & 0,2 & 157 & 0,4 & 416 & 1,1 \\
\hline 0,5 a 1 & 217 & 0,9 & 467 & 1,5 & 665 & 1,7 & 427 & 1,2 \\
\hline 1 a 1,5 & 5.240 & 22,3 & 8.303 & 27,1 & 9.311 & 23,7 & 8.022 & 21,7 \\
\hline 1,5 a 2 & 8.333 & 35,5 & 10.545 & 34,4 & 13.736 & 34,9 & 12.320 & 33,3 \\
\hline 2 a 3 & 5.877 & 25 & 6.147 & 20 & 8.758 & 22,3 & 8.335 & 22,5 \\
\hline 3 a 4 & 1.507 & 6,4 & 1.423 & 4,6 & 1.952 & 5 & 2.026 & 5,5 \\
\hline 4 a 5 & 997 & 4,2 & 1.749 & 5,7 & 2.225 & 5,7 & 2.531 & 6,8 \\
\hline 5 a 7 & 541 & 2,3 & 722 & 2,4 & 937 & 2,4 & 861 & 2,3 \\
\hline 7 a 10 & 308 & 1,3 & 595 & 1,9 & 769 & 2 & 935 & 2,5 \\
\hline Mais de 10 & 200 & 0,9 & 248 & 0,8 & 256 & 0,7 & 230 & 0,6 \\
\hline \{ñ Glas9 & 248 & 1,1 & 416 & 1,4 & 590 & 1,5 & 871 & 2,4 \\
\hline Total & $\mathbf{2 3 . 4 8 5}$ & $\mathbf{1 0 0}$ & $\mathbf{3 0 . 6 7 6}$ & $\mathbf{1 0 0}$ & $\mathbf{3 9 . 3 5 6}$ & $\mathbf{1 0 0}$ & $\mathbf{3 6 . 9 7 4}$ & $\mathbf{1 0 0}$ \\
\hline
\end{tabular}

(MTE - Relação Anual de Informações Sociais)

Para além das atividades envolvendo o cultivo da soja e a cadeia agroindustrial carnes/grãos, também as atividades de construção civil e manutenção do espaço urbano vêm absorvendo uma parcela crescente da força de trabalho no estado do Mato Grosso, como resultado da crescente urbanização da economia e da sociedade do "agronegócio". Durante as últimas décadas complexificou-se a hierarquia urbana mato-grossense, ampliando-se e proliferando-se novas cidades com porte médio entre 50 a 100 mil habitantes como pontos nodais dos circuitos produtivos e de circuitos dos cooperação que articulam a produção e o consumo locais às economias regional, nacional e global. Denominadas "cidades do agronegócio" por Elias, estes núcleos urbanos são hegemonizados pelas demandas da agricultura e agroindústrias globalizadas e concentram estoques de meios de consumo, meios de produção e mão de obra com diferentes níveis de qualificação, estruturas de armazenamento, processamento industrial e escoamento da produção, além de escritórios de agroindústrias, tradings e demais instituições comerciais e financeiras operando em escala 
global. (Elias e Pequeno, 2007). Consequentemente, parte significativa da força de trabalho no estado tem sido empregada em atividades de construção e manutenção destes espaços urbanos nas últimas décadas. As tabelas 9 e 10 trazem informações com base na RAIS acerca de trabalhadores empregados no estado na construção de edifícios (CNAE 4120-4/00), em obras de urbanização como ruas, praças e calçadas (CNAE 4213-8/00) e na construção de redes de abastecimento de água, coleta de esgoto e construções correlatas (CNAE 4222-7/01). Como já destacado, também na construção civil é perceptível um aumento expressivo no grau de escolaridade dos operários: em 2006 os trabalhadores com até o ensino fundamental completo representavam $67,5 \%$ dos empregados com carteira assinada na construção civil em Mato Grosso caindo a 39,9\% em 2018, enquanto a participação de trabalhadores com ensino médio incompleto e completo aumentou de $28,5 \%$ a 52,9\%. Entretanto, o nível de remuneração elevou-se mas não acompanhou este aumento expressivo da qualificação: em 2006 os trabalhadores com 1 a 2 salários mínimos representavam 70,6\% dos empregados com carteira assinada na construção civil em Mato Grosso caindo para 64,4\% em 2018, enquanto a participação de trabalhadores com remuneração de 2 a 5 salários mínimos subiu de $24,6 \%$ a $30,5 \%$ neste mesmo período. 
Tabela 9: Número de pessoas empregadas com carteira assinada na construção de edifícios, em obras de urbanização e na construção de redes de água e esgoto por grau de escolaridade no Mato Grosso entre 2006 e 2018

\begin{tabular}{c|c|c|c|c|c|c|c|c}
\hline $\begin{array}{c}\text { Grau de } \\
\text { escolaridade }\end{array}$ & $\mathbf{2 0 0 6}$ & $\%$ & $\mathbf{2 0 1 0}$ & $\mathbf{2}$ & $\mathbf{2 0 1 4}$ & $\mathbf{\%}$ & $\mathbf{2 0 1 8}$ & $\%$ \\
\hline Analfabeto & 128 & 1,77 & 287 & 1,67 & 251 & 1,23 & 178 & 1,23 \\
\hline $\begin{array}{c}\text { Fundamental } \\
\text { I incompleto }\end{array}$ & 593 & 8,21 & 1.805 & 10,5 & 2.294 & 11,26 & 1.376 & 9,49 \\
\hline $\begin{array}{c}\text { Fundamental } \\
\text { I completo }\end{array}$ & 1.464 & 20,26 & 1.999 & 11,63 & 1.395 & 6,85 & 612 & 4,22 \\
\hline $\begin{array}{c}\text { Fundamental } \\
\text { II incompleto }\end{array}$ & 1.535 & 21,25 & 2.912 & 16,94 & 2.426 & 11,91 & 1.532 & 10,56 \\
\hline $\begin{array}{c}\text { Fundamental } \\
\text { II completo }\end{array}$ & 1.155 & 15,99 & 2.753 & 16,01 & 2.801 & 13,75 & 2.094 & 14,44 \\
\hline $\begin{array}{c}\text { Médio } \\
\text { incompleto }\end{array}$ & 912 & 12,62 & 2.156 & 12,54 & 2.064 & 10,13 & 1.441 & 9,94 \\
\hline $\begin{array}{c}\text { Médio } \\
\text { completo }\end{array}$ & 1.119 & 15,49 & 4.465 & 25,97 & 7.793 & 38,26 & 6.227 & 42,94 \\
\hline $\begin{array}{c}\text { Superior } \\
\text { incompleto }\end{array}$ & 101 & 1,4 & 231 & 1,34 & 450 & 2,21 & 285 & 1,97 \\
\hline $\begin{array}{c}\text { Superior } \\
\text { completo }\end{array}$ & 218 & 3,02 & 587 & 3,41 & 894 & 4,39 & 750 & 5,17 \\
\hline Mestrado & 0 & 0 & 0 & 0 & 0 & 0 & 7 & 0,05 \\
\hline Total & $\mathbf{7 . 2 2 5}$ & $\mathbf{1 0 0}$ & $\mathbf{1 7 . 1 9 5}$ & $\mathbf{1 0 0}$ & $\mathbf{2 0 . 3 6 8}$ & $\mathbf{1 0 0}$ & $\mathbf{1 4 . 5 0 2}$ & $\mathbf{1 0 0}$ \\
\hline
\end{tabular}

(MTE - Relação Anual de Informações Sociais) 
Tabela 10: Número de pessoas empregadas com carteira assinada na construção de edificios, em obras de urbanização e na construção de redes de água e esgoto por faixa de remuneração no Mato Grosso entre 2006 e 2018

\begin{tabular}{c|c|c|c|c|c|c|c|c}
\hline $\begin{array}{c}\text { Faixa de } \\
\text { remuneração } \\
\text { média (SM) }\end{array}$ & $\mathbf{2 0 0 6}$ & $\mathbf{\%}$ & $\mathbf{2 0 1 0}$ & $\mathbf{\%}$ & $\mathbf{2 0 1 4}$ & $\mathbf{\%}$ & $\mathbf{2 0 1 8}$ & $\mathbf{\%}$ \\
\hline Até 0,5 & 10 & 0,14 & 69 & 0,4 & 70 & 0,34 & 103 & 0,71 \\
\hline 0,5 a 1 & 305 & 4,22 & 562 & 3,27 & 520 & 2,55 & 379 & 2,61 \\
\hline 1 a 1,5 & 2.834 & 39,22 & 6.221 & 36,18 & 5.755 & 28,26 & 4.664 & 32,16 \\
\hline 1,5 a 2 & 1.955 & 27,06 & 4.987 & 29 & 6.239 & 30,63 & 4.197 & 28,94 \\
\hline 2 a 3 & 1.268 & 17,55 & 3.197 & 18,59 & 4.670 & 22,93 & 3.374 & 23,27 \\
\hline 3 a 4 & 349 & 4,83 & 915 & 5,32 & 1.454 & 7,14 & 811 & 5,59 \\
\hline 4 a 5 & 160 & 2,21 & 383 & 2,23 & 591 & 2,9 & 247 & 1,70 \\
\hline 5 a 7 & 130 & 1,8 & 356 & 2,07 & 440 & 2,16 & 201 & 1,39 \\
\hline 7 a 10 & 72 & 1 & 198 & 1,15 & 224 & 1,1 & 103 & 0,71 \\
\hline Mais de 10 & 24 & 0,34 & 103 & 0,51 & 103 & 0,51 & 53 & 0,37 \\
\hline \{ñ class & 118 & 1,63 & 204 & 1,19 & 302 & 1,48 & 370 & 2,55 \\
\hline Total & 7.225 & $\mathbf{1 0 0}$ & $\mathbf{1 7 . 1 9 5}$ & $\mathbf{1 0 0}$ & $\mathbf{2 0 . 3 6 8}$ & $\mathbf{1 0 0}$ & $\mathbf{1 4 . 5 0 2}$ & $\mathbf{1 0 0}$ \\
\hline
\end{tabular}

(MTE - Relação Anual de Informações Sociais)

Assim como destacamos dentre os trabalhadores nas agroindústrias de carnes, estas transformações no perfil dos trabalhadores têm sido acompanhadas da permanência de condições precárias de trabalho e de integração nos espaços urbanos de Mato Grosso. Segundo o Anuário Estatístico de Acidentes de Trabalho do Ministério da Previdência, o Mato Grosso foi em 2013 o estado com a maior taxa de mortalidade dentre trabalhadores da construção civil no Brasil, contribuindo para que o Mato Grosso liderasse o ranking de mortes por acidentes de trabalho no país com 626 ocorrências entre 2012 e 2017, alcançando a média impressionante de uma morte a cada 5.700 habitantes enquanto nas demais Unidades da Federação o índice foi de uma morte para 14.500 habitantes (Hipernotícias, "Com 120 casos por ano, Mato Grosso lidera ranking de mortes por acidentes do trabalho no Brasil", 09/05/2017). Paralelamente, os espaços urbanos erguidos por esta força de trabalho têm sido dirigidos por iniciativas de especulação fundiária que criaram de maneira artificial a escassez de terras por meio da proliferação de espaços vazios, pressionando as levas migrantes que para lá se dirigiram a ocupar áreas distantes precariamente atendidas por serviços públicos 
enquanto se multiplicaram condomínios fechados para classes médias e altas amedrontadas pela violência urbana. Criam-se assim espaços urbanos altamente segregados que cristalizam na consciência popular e na vida cotidiana do precariado subordinado ao "agronegócio" as angústias e frustrações decorrentes de sua permanente subalternidade econômica e política.

\section{Conclusão}

Este artigo propôs-se examinar traços fundamentais do processo de formação da classe trabalhadora subordinada ao "agronegócio" no estado do Mato Grosso. Acompanhamos durante a segunda metade do século XX tanto a proliferação de peões, de garimpeiros e de prostitutas submetidos à super-exploração de sua força de trabalho, quanto a emergência de trabalhadores dotados de novo perfil em fazendas de milho e soja, em agroindústrias processadoras de grãos e carnes e em atividades da construção civil. Pudemos ver que a expansão da soja e da cadeia carnes/grãos e a concomitante urbanização da economia e da sociedade do "agronegócio" tem sido acompanhadas da consolidação de um mercado de trabalho livre assalariado que crescentemente assume o lugar das relações de produção predominantemente mediadas por mecanismos de coerção extra-econômica e características da acumulação primitiva em meio à fronteira agrícola.

Observamos, contudo, que trabalhadores assalariados no interior de fazendas de soja e milho, de agroindústrias de grãos e carnes e em atividades da construção civil em Mato Grosso seguem submetidos a rígidos obstáculos a sua ascensão social por meio dos canais estreitos abertos pela economia e pela sociedade do assim chamado "agronegócio". Via de regra, como acompanhamos ao longo deste artigo, aumentos significativos da qualificação desta força de trabalho não tem se traduzido em melhorias tanto em seu nível de remuneração, quanto em suas condições de trabalho durante as últimas duas décadas. A maior escolarização assume a forma de uma crescente frustração e angústia perante a contínua reprodução da subalternidade econômica e política desta fração de classe, corporificada em espaços urbanos marcados por uma rígida segregação entre classes sociais e entre raças dentre as principais cidades produtoras de grãos no estado.

Tal inquietação social crônica destes trabalhadores parece ainda assumir predominantemente a forma de uma excepcional rotatividade e de um contínuo deslocamento circular entre "cidades do agronegócio" no Mato Grosso e seus diferentes estados de origem na região Nordeste, com destaque especialmente para o Maranhão. Trata-se de trabalhadores marcados por uma hibridez em que se fundem diferentes modos de vida e distintas temporalidades da história: saem do Maranhão ao Mato Grosso em resposta à corrosão de seu mundo tradicional rural e retornam do Mato Grosso ao Maranhão em resposta ao caráter estreito tanto do mundo do trabalho, quanto do espaço urbano nos principais polos produtores de soja e milho ou processadores de grãos/carnes. Longe de um estado de espírito marcado pela satisfação ou passividade, esta fração da classe trabalhadora corporifica os impasses do processo de modernização no Brasil que lhes aparece como a experiência do trecho, ou seja, uma infindável fuga para frente. 


\section{Bibliografia}

ARACRI, Luís Ângelo dos Santos. Sistemas de produção agrícola e meio técnico-científico-informacional: A difusão da agricultura de precisão e a modernização do espaço agrário em Mato Grosso. Tese de doutorado em Geografia. Universidade Federal do Rio de Janeiro (UFRJ). Rio de Janeiro: 2010.

BALSADI, Otávio Valentim. O mercado de trabalho assalariado na agricultura brasileira e suas diferenciações regionais no período 1992-2004. São Paulo: Editora Hucitec, 2008.

BARROZO, João Carlos. Em busca da pedra que brilha que nem estrela: Garimpos e garimpeiros do Alto Paraguai - Diamantino. Cuiabá: EdUFMT, 2007.

BERNARDES, Júlia Adão. Técnica e trabalho na fronteira de expansão da agricultura moderna brasileira. In ARRUZZO, Roberta Carvalho (org.). Formas em crise: utopias necessárias. Rio de Janeiro: Arquimedes edições, 2005.

BRAGA, Ruy. A política do precariado: do populismo à hegemonia lulista. São Paulo: Editora Boitempo, 2012.

CAMARGO, Kelly Cristina de Moraes. Expansão da Soja e Dinâmica Sociodemográfica no Mato Grosso. VII Congreso de la Asociación Latinoamericana de Población e XX Encontro Nacional de Estudos Populacionais, Vol. 1, pp.1-21, Foz do Iguaçu, PR, Brasil, 2016.

CUNHA, José Marcos Pinto da. A migração no Centro-Oeste brasileiro no periodo de 1970-1996: O esgotamento de um processo de ocupação. Campinas: Núcleo de Estudos de População/Unicamp, 2002.

CUNHA, José Marcos Pinto da. A dinâmica migratória e o processo de ocupação do Centro-Oeste brasileiro: o caso de Mato Grosso. Campinas: Núcleo de Estudos de População/Unicamp, 2011.

CUNHA, José Marcos Pinto da. A migração interna no Brasil nos últimos cinquenta anos: (des)continuidades e rupturas. In: ARRETCHE, M. Trajetórias das desigualdades: como o Brasil mudou nos últimos cinquenta anos. São Paulo: Editora UNESP; CEM, 2015.

DIMENSTEIN, Gilberto. Meninas da noite: a prostituição de meninas escravas no Brasil. São Paulo: Editora Ática, 1992.

ELIAS, Denise; PEQUENO, Renato. Desigualdades socioespaciais nas cidades do agronegócio. Revista Brasileira de Estudos Urbanos e Regionais, V. 9, N. 1, maio/2007.

ESTERCI, Neide. Conflito no Araguaia: Peões e posseiros contra a grande empresa. Petrópolis: Vozes, 1987. 
ESTERCI, Neide. Escravos da desigualdade: um estudo sobre o uso repressivo da força de trabalho hoje. Rio de Janeiro: Centro Edelstein de Pesquisas Sociais, 1994.

FIGUEIRA, Ricardo Rezende. Pisando fora da própria sombra: A escravidão por dívida no Brasil contemporâneo. Rio de Janeiro: Civilização Brasileira, 2004.

FIGUEIRA, Ricardo Rezende, CERQUEIRA, Gelba Cavalcante; OLIVEIRA, Maria Amália Silva Alves. Representações sociais de mulheres de ambiente, donas de pensão e parentes de trabalhadores submetidos à escravidão. In CERQUEIRA, Gelba Cavalcante de; FIGUEIRA, Ricardo Rezende; PRADO, Adonia Antunes; COSTA, Célia Maria Leite (orgs.). Trabalho escravo contemporâneo no Brasil: contribuições críticas para sua análise e denúncia. Rio de Janeiro: Editora da UFRJ, 2008.

INSTITUTO MATO-GROSSENSE DE ECONOMIA AGROPECUÁRIA (IMEA). Pesquisa sobre mecanização agrícola em Mato Grosso. In http://www.imea.com.br/imea-site/view/uploads/estudos-customizados/ApresentacaoMecanizacao Agricola-2015.pdf, Junho 2015

$$
\text { Agronegócio em Mato Grosso. In }
$$

http://imea.com.br/upload/pdf/arquivos/2012_09_13_Apresentacao_MT.pdf, Agosto 2012.

LE BRETON, Binka. Vidas Roubadas: A escravidão moderna na Amazônia brasileira. Loyola: São Paulo, 2002

LIMA, Maria Arlinda da Silva. Garimpo e ocupação territorial: efeitos sociais provocados pela atividade garimpeira em Peixoto Azevedo - MT (1978-1990). Dissertação de mestrado em História. Universidade Federal de Mato Grosso (UFMT). Cuiabá, 2009.

MARTINS, José de Souza. Fronteira: a degradação do Outro nos confins do humano. São Paulo: Hucitec, 1997.

PASCA, Dan. Garimpo e meio ambiente: O caso de Poconé/Mato Grosso. Caderno do NERU, n.3, setembro de 1994 .

PLASSAT, Xavier. CPT: 30 anos de denúncia e combate ao trabalho escravo. In https://www.cptnacional.org.br/multimidia/49-noticias/trabalho-escravo/2634-cpt-30-anos-dedenuncia-e-combate-ao-trabalho-escravo, Maio de 2015.

RUMSTAIN, Ariana. Peões no trecho: Trajetórias e estratégias de mobilidade no Mato Grosso. Rio de Janeiro: E-papers, 2012.

SALOMÃO, Elder Prata. Garimpos no Tapajós. Ciências da Terra, nº 1, nov/dez 1981.

SOUZA, Ana Maria de. Relatos da cidade: Nomadismo, territorialidades urbanas e imprensa (Cuiabá-MT). Cuiabá: EdUFMT, 2007. 
SOUZA, Edison Antônio de. Sinop: História, imagens e relatos - Um estudo sobre sua colonização. Cuiabá: Instituto de ciências humanas e sociais, 2004.

THERY, Hervé; MELLO, Neli Aparecida de; HATO, Julio; GIRARDI, Eduardo. Atlas do Trabalho Escravo no Brasil. São Paulo: Amigos da Terra, 2009.

TRINDADE, Roberto de Barros Emery; FILHO, Olavo Barbosa. Extração de ouro: princípios, tecnologia e meio ambiente. Rio de Janeiro: CETEM/MCT, 2002.

WESZ JÚNIOR, Valdemar João. Dinâmicas e estratégias das agroindústrias de soja no Brasil. Rio de janeiro: E-papers, 2011.

WESZ JÚNIOR, Valdemar João. O mercado da soja e as relações de troca entre produtores rurais e empresas no sudeste de Mato Grosso (Brasil). Tese de doutorado em Ciências Sociais. Universidade Federal Rural do Rio de Janeiro (UFRRJ). Rio de Janeiro, 2014.

\section{COMO CITAR ESTE TRABALHO}

FARIAS, Luiz Felipe Ferrari Cerqueira de. Metamorfoses do trabalho no estado do Mato Grosso - Brasil. Revista Tamoios, São Gonçalo, v. 18, n. 1, p. 117-143, 2022. Disponível em: https://doi.org/10.12957/tamoios.2022.63798. Acesso em: DD MMM. AAAA. 